1935

\title{
Thyrotoxicosis during pregnancy
}

George H. Lord

University of Nebraska Medical Center

This manuscript is historical in nature and may not reflect current medical research and practice. Search PubMed for current research.

Follow this and additional works at: https://digitalcommons.unmc.edu/mdtheses

Part of the Medical Education Commons

\section{Recommended Citation}

Lord, George H., "Thyrotoxicosis during pregnancy" (1935). MD Theses. 636.

https://digitalcommons.unmc.edu/mdtheses/636

This Thesis is brought to you for free and open access by the Special Collections at DigitalCommons@UNMC. It has been accepted for inclusion in MD Theses by an authorized administrator of DigitalCommons@UNMC. For more information, please contact digitalcommons@unmc.edu. 
THYROTOXICOSIS DURING PREGNANCY

by

George H. Lord

Subnitted to the Faculty of the University of

Nebraska College of Medicine in Partial

Fulfiliment of the Requirements

for the Degree of Doctor

of Medicine

1935 


\section{CONTENTS}

Introduction

Page 1

Anatomy, Physiology and Pathology --.--

The Thyrotoxic State

Relationship of the Thyrold to Pregnsncy --- Page 17

Thyrotoxicosis During Pregnancy _....... Page 21

Clinical Considerations

Case I -a M11d Type -

Case II -- Acute Type -

Treatment -

Conclusions -

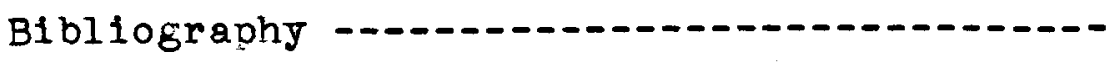


Introduction

There is no complication of pregnancy about which more $1 \mathrm{~s}$ known and yet presents so much difference of opinion as in the subject of hyperthyroidism during pregnancy. The pathological physiology as well as etiology of the toxemias of pregnancy are things which everyone seems to pass up with the three words, "We don't know", In the final clause of the discussion. The treatment is to a certain degree favoruble. In thyrotoxicosis during pregnuncy, the etiology and pathology as well as the treatment have been worked out to the point where nothing is left for speculation and theorizing, and yet the ideas of almost every writer differ in major questions of the problem.

This discussion is an effort to present the ideas of the authorities on the subject. As will be apparent later, this is difflcult to do since these idess are so completely different. The subject of hypothyroidism has received only little space and there has been an effort to amit it in the discussion in so $f: r$ as possible. However, references are made to the condition more especially in the discussion of the physlology of the thyrold Bland. the 
reason for this is that most fiajor physiological observations were made under experimental hypo- and hyperthyrold$1 \mathrm{sm}$.

The thyrold gland in its relationship to the other endocrine glands is a subject within itself. Only concrete evidences of experimental nature which seem to indicate what actualiy happens in the thyroid gland when pregnancy occurs has been presented. The remainder I have not stressed because there is so much theorizing which I have attempted to eliminate from what I have tried to make a practical discussion of my subject. 
Resume of the Anatomy, Physiology, and Pathology of the Thyrold Gland

The thyrold gland consists of two lobes jolned together across the trachea by a narrow transverse portion called the 1sthmus. It extends from the junction of the inidale with the lower third of the thyrold cartilage downwards to the level of the fifth or the sixth.tracheal ring. It normally welghs one ounce in the male and slightly more than this in the female. Emmert (15) points out that the isthmus at times is absent and that there is at times a third lobe called the pyramid which arises from the 1sthmus or left lobe and extends upward as far as the hyold bone. It may be entirely separated from the gland and be divided into several parts. The fland is enveloped In a connective tissue capsule which is thin anteriorly and increases in thickness as it passes around toward the posterlor surface.

Mayo and Plummer (34), In a very complete discussion of the anatomy, physlology, and pathology of the thyroid gland, call our attention to the fact that the gland is rlchly supplied with blood. the superior tnyrold arteries enter each superior pole and anastomose freely 
xith the inferior thyroids which enter the lower pole of each lobe. At times the thyroid ima, a small vessel arising from either the innominate or the arch of the aorta, ascends the anterior surface of the trachea and supplies the lower portion of the gland. The veins are numerous and large and follow the main arterles, except for the middle thyroldal veins which leave the gland from either side and empty into the innominate veins. Much more was known in the past of the anatomy of the thyrold gland than of its function. Crott1 (7) in his very interesting alscussion of the history of the thyroid sland enumerates several most fascinating theories as to the physiology of the gland. He shows how the physiologists of antiquity considered the thyroid as a cosmetic organ whose function it was to produce a nice soft roundness of the neck. Others considered it as a mechanical support to the larynx and thought that it protected this organ from the cold. Another group of men considered the fland as one of external secretion, its secretion bein poured into the region of the vocal cords and furnishing the necessary lubrication to these cords. Still others considered a communication with the esophagus and marked the excretory canal as being at the foramen cecum. 
A new and more scientific observations were being made all along, the extreme vascularity of the thyrold gland was noticed. This set off a new line of thought. The gland was consldered as a mechanical regulatory. organ of the blood stream, its engorgement resulting in pressure on the carotid vessels with a cerebral anemia, a sort of safety valve for the cerebral clrculation. Along this same time, one observer considered the fland as the organ of sleep by the mechanism brought out above and cerebral anemia resulting in unconsclousness.

At the present time physiological studies are made under conditions of experimental hyperthyroidism by feeding thyroid substance and by experimental hypothyroldism as by removal of the thyrold gland in animals. It was along these lines that the observations of Kocher and Reverdin were directed.

Probably the first true sclentific observation made, according to Ward (45) (46), was that of Parry in 1786. Parry observed hyperthyroidism but his observations were not accepted and the syndrome was as much unexplained as previously. In 1835 Graves made his epoch making discoverles and the subjects of thyrold physlology and pathological physiology were much advanced. 
In the beginning it had been observed that if thyroid substance is given to animals or humans a certain train of toxic symptoms occur. This comolex, made up of exopthalmas, tremor, loss of welght, trachecardia, headache, polyphagia, vert1go, mental excitation, nausea, vomiting, polyuria, albuminuria, and flycosuria, was called acute thyroldism and ocours as we see it today in the hyperthyroid state.

Orotti (7) sums up the physiological activities of the thyrold gland under seven headings:

1. Heat regulation: Experiments in which thyroid substance was fed to hybernating animals revealed an increased temperature and activity.

2. Action on the cardioviscular system. When thyrold extract was given by vein there was a lowering of the blood pressure and a peripheral vasodilatation. Phere are numerous theories as to the mechanism of this phenomenon all of which have their strenuous advocators and opposers. 3. action on the blood. After complete thyroldectomy, an anemia resulted which returned to the normal state after thyrold feeding. Is it hemopoleticr

4. Action on nutrition. In the symptom complex of acute thyroldism the metabolism is whipoed up, the oxidat- 
Ive processes are more rapid in each cell in the body, more waste products are being formed and more food utilized.

5. Action on the osseous system. Following total thyroidectomy, trophlc disturbances were observed in the osseous system. It was noticed that the younger the animal the more pronounced these trophic changes.

6. Action on the nervous system. A severe neuritis was demonstrated after complete thyroldectomy in the laboratory unimal which followed in most cases by a parenchymatous encephalitis. In the hyperthyroid state It $1 \mathrm{~s}$ of common observation that the patient has an hyperactive nervous system with tendency to emotional instability and pronounced tremor. No mleroscopic changes in the nerves have ever been reported in hyperthyroldism however.

7. Modification of the urine. In hyperthyroidism there is an increase in the urine output with a high phosphate. In hypothyroldism there may be a febrile albuminuria.

Much experimental work has been done in the past few years in an attempt to place the thyroid in the physlological "endocrine chain". The work of Knaus (25) (26) and others should be mentioned. 
Knaus (25) injected virginal rats from two to four weeks with extracts from the corpus luteum. He reports a thyrold hypertrophy with an increase in the amount of the colloid in these goiters. From his observations he concludes that the corpus luteum causes an inhlibition of the output of thyroid secretion. However, he found that these animals gained welght which speaks against hyperthyroidism. The analogy of the findings of Knaus with the changes in the thyroid during pregnancy is very close as will be pointed out later.

Loeb and Bassett (28) removed the anterior oltuitary of rats and observed an atrophy of the thyrold gland. A standard pituitary extract (Armours) wa fed and the thyrold falled to regenerate. These workers then prepared both acid and alkaline extracts of the dried anterior pituitary of cattle and promptly got an hypertrophy of the thyrold gland whlch previously had been partially removed. This observation was also made by Bothe (5) who, besides demonstrating glandular hyoertrophy following pituitary injections, demonstrated an increased secretion of the gland as measured in the blood. Ansilmino and Hoffman (1) (2) demonstrated the presence of thyroxin (or a substance having the character1stics of thyroxin) in the blood of normal men and women 
and showed quite conclusively that there was a marked Increase during pregnancy which reached 1ts highest level toward the end of pregnancy and drooped to normal after delivery. These men also demonstrated an increased carbon dioxide output in rats that had ihad dally injections of pregnant human serum with no demonstrable increase in the carbon dioxide output when the injections were done with normal human serum. Clute and Daniels (8) bring out the importance of the thyroid-ovartan interrelationship. Their conclusions were that the more active the thyroid, the less active the ovry and this is borne out in a practical way when the extremely low incldence of hyperthyroldism associated with pregnancy is brought out.

Knaus (26) made Intraveneous injections of $0.02 \mathrm{mg}$. of epinephrine in thirty five multiparas and primiparas In the later half of pregnancy, lmmediately followed by subcutaneous injections of 0.8 to one $m_{8}$. of epinephrine. From the responses that he got in this experimental work seem to indicate that epinephrine causes a decrease in the thyroid secretion and that pregnancy edema may bo adequately combated by the use of thyrold extract. He concludes that there is some hook up between the thyrold secretion and the toxemias of oregnancy. The work of Fruhinsholz (19) seems to bear out this conclusion since 
he observed four cases of myxoedema and oregnancy all of which presented some findings of preonancy toxemia. Marine and his coworkers (31) (32), in an experimental study on elghteen pregnant rats showed that after lodine had been fed that there was no change in the heat poduction in eleven, an increase in two, and a decrease in five. At term pathologicul studies of the gland showed no apparent change or difference. However, steward and Meane (42) in a study of pregnant rabbits demonstrated a smaller incresse in basal metabolic rate $(3.6 \%--2.9 \%)$ where physiolosical doses of lodine were olven than in those in which no lodine had been given $(39.2 \%--45 \%)$

With the accumalation of experimental material which has been brought out in the past few years, there have been no specific conclusions drawn as to the exact role the thyroid plays in relationshlp to the other endocrine glands or the speciflc effect lodine plays in thyrold metabolism other than to say that it seems to render some unknown element usable and to reduce the toxicity of a toxic thyroid gland.

Pathologlcally, Boyd (6) polnts out that the thyrold Giand is peculiax in that it is only seldom affected by 
the four great causes of disease elsewhere in the body namely inflammation, tuberculosis, syohilis, and

mallgnant disease. However, it commonly oresents a condtion of enlargement, diffuse or localized, which may or may not be accompanied by symptoms of grave disturbance of B̈eneral metabolism. Numerous discriptive terms have been used in the past to indicate certain processes which have taken place in the gland. Such terms as parerchymatous golter, hyperplast1c golter, non hyperplast1c golter. cystic golter, etc, have resulted in much confusion in pathological studies. At present however, with the increased understanding in morbid processes in the gland, these states are, as pointed out by virchow (43), only part of a general pathological entity.

The pathogenesis of goiter is well ofiven by Boyd (6). He states that "the thyroid, as already indicated, maf be played upon by a variety of stimulae, to which it reacts by hyperplasia, elther of the adult or of the embryonic cells, It does not follow therefore, that it is necessary to look for one constant and Invariable cause of goiter. In some cases it may be due to bacterial infection which possibly uses up the lodine necessiry for the normal functioning of the gland in others it may be due to 
- deficiency of lodine in the food, in others to physiological stimulae such as puberty, menstruation, and pregnancy, in jet others to sever psychic shock as for instance in the cases of exophthalmic goiter which developed suddenly upon bombardment of towns during the world war. Even these cases may be merely demands for a greater lodine supply than is available. The stimulus is followed by hyperplasia. When the stimulus is withdrawn the hyperplasia ceases, and the gland returns to normal. Such for instance, is the thyroid enlargement of menstruation and pregnancy. Everything depends upon how far the hyperplasia has gone. If it is very slight the gland may return to normal. If it has proceeded further the best that can be done is a return to a resting staye in which the gland is permanently damaged, a condition of collold goiter. If the stimulus is continued, the hyperplasia progresses indefinitely".

With a fundimental understanding of the ohysiolosical and pathological processes as outlined above, comes an understanding of the complicated picture that is presented in the hyperthyrold state.

The clinical classifications of goiter are as complicated as the pathological discussions. For pract- 
Ical considerations the classification suggested by the Committee on Classification appointed by the American Medical Association for the study of Golter is complete. It is as follows:

Type I. Non Toxic Diffuse Golter

Type 2. Toxic Diffuse Golter

Type 3. Hon Toxic Nodular Golter

Type 4. Toxic Nodular Golter

The older writers use the older classification of thyrold disturbances, which is as follows:

Type I. Colloid Golter

Type 2. Non Toxic Adenomatous Golter

Type 3. Toxic Adenanatous Golter

Type 4. Sxophthalmic Goiter

This classification, though less convenient from a clinical standpoint, w11l be used throughout this discussion in order that misinterpretation of the I1terature w1ll be avolded. 
The Thyrotoxic State--Bxophthalmic Goiter and Toxic Adenoma

The clinical picture of these two conditions may best. be understood by quoting the descriotion of Boothby (4). He states that "exophthatmic golter may be described as a constitutional disease, apparently due to an excessive, probably abnormal secretion of an enlarsed thyroid gland showling diffuse parenchymatous hypertrophy; it is charecterized by a high basal metabolic rate with the resulting manifestations, with a peculiar nervous syndrome, and with a tendency toward the gastrointestinal crisis af vomiting and diarrhea. In contrast, the symptoms of adenomatous golter are those essentially due to a prolonged elevation of the basal metabolic rate caused by the presence in the tissues of an excess of a normal thyroid secretion exophthalmos doesnot occur and the symptoms are not assoclated with tyọcal diffuse parenchymatous hypertrophy but with the occurence of adenomatous tissue of the thyriod gland. At least one third of all exophthalmlc golters have superimposed adenomas"

The clinical picture of an exophthalmic goiter is quite variable. Early there may be a sense of fatigue .w1th nerrous exc1tablilty and loss of welght. The 
appetite may be excessive and in spite of the increasing fatigue, there may be an inward drive urging the patient on to purposeless activity. The skin is usually warm and flushed and the patient perspires easily.

Mayo and Plummer (34) list the symptoms of exophthalmic golter in order of their importance.

1. Palpitation. The cardiac rute may reach 160 and is persistant during sleep. Auricular fibrillation is common.

2. Warm damp skin. Whth flushing of the face and generalized superficial vasodilitation.

3. Tremor. The patient suffers from a constant intention tremor which seems to get worse as time goes on.

4. Eye changes, cosisting of:

a. Exophthalmos with a more or less fixed staring expression, the eyes are unusually bright.

b. Infrequent blinking--stellwass sign.

c. Weakness on convergence--Moeblus sign.

d. Lid lag--on looking downward the uoper lid follows slowly or not at all. von Graefe's sign.

5. Nervous manifestations. There may be nervous instablity with unexpected losses of temper. 'irue psychosis occasiongliy occurs. 
6. Tumor in the neck. This finding may be marked or ent1rely absent. A "bruit de diadle" may be demonstrated over the gland.

The findings of a toxic adenoma are much the same as those listed above with a few exceptions. Th1s conditIon, as brought out by Wallace (44), occurs at a later time in $11 f \theta$ and thus the relative infrequency of adenoma in pregnancy. Also, the eye changes listed above are, accordins to Du Bois (14), seldom a part of the clinical p1cture. He brings out an 1mportant fact when he states that "the constitutional symptoms of toxemia from adenoma often come without apparent cause but is sometimes initlated by the administration of lodine and once started, continues even after the lodine has been withdrawn". 
The Relation of the Phyrold Gland to Pregnancy

The profound changes which result in the female from pregnancy have been recorded by almost all writers. That Influence the thyrold gland has is bringing about these changes is questionable, but such authorities as Falls (17), Mussey and Plumer (35), Wallace (44), Yoakam (48), Bothe (5), Davis (11) (12), and Beck (3) all agree that the early physical manifestations of pregnancy may be placed in general on a basis of change in the endocrine interrelatlonshlps and more specifically on the basis of an increased thyrold secretion. The symptoms associated with early pregnency of nausea, vomitinğ, nervouseess, increased excitability, and tachecardia, associated with an 1ncrease In size of the thyrold gland are commonly seen. "At times there mas even be slight exophthalmos. This is especially brought out by Falls (17).

Yoakam (48), who has made extensive studies in regions of endemio golter, comes to the conclusion that the demands on the thyroid gland are increased during pregnancy and an hypertrophy of that organ results.. He points out that this is especially true if the lodine Intake $1 \mathrm{~s}$ Impalred as it was where his studies were made. 
However, later in his article he states that "the so called physlological enlargement of the thyroid filand is in reality a pathologlc hyperplasia which may be prevented by the administration of sufficient lodine In the diet during pregnancy".

Marine (30) states that there is always some decrease In the lodine content of the thyroid gland during pregnancy showing the necessity of lodine administration during sestation. He also brings out the fact that in areas of endemic goiter the incidence of low lodine content In the thyroids of bables born of golterous mothers and strongly urges the use of lodine to prevent the maternal hypertrophy and to increase the lodine content of the fetal thyroid gland so preventing consenital goiter. Soule (4l) made studies of the thyroid gland in normal pregnancy and demonstrited that the glycosen level In the body was decreased with any increase in the activity of the thyrold gland. we also demonstrated a higher concentration of thyroxin in the maternal blood than in the blood of the fetus.

the findings of xnaus (25) (26) seem to indicate, as was brought out above, that there is some connection between the corpus luteum and thyroid hypertroohy. It is 
known that the corous luteum continues its hypertrophy and internal secretory powers well into pregnancy as the corpus luteum vera. Whe work of Kngus seems to indicate that this new gland of internal secretion causes the thyrold hypertrophy so commonly seen during pregnancy, since he got thyroid hypertrophy in vireinal rats with injections of corpus luteum substance.

Falls (17) sums up the endocrine state by saying that "It is not easy to explain what actually happens in these but we believe that there is a stimulation of the sympathetic nervous system and all the olands of internal secretion. As a result there is a readjustment of these 6 lands relationship to each other and to the organism as a whole. When the readjustment occurs in the right direction, the golter symptoms do not appear or are 1mproved but when it occurs in the reverse direction the toxic phenomona are agsravated".

There has been much work of late in an attempt to determine the exact state of the metabolic orocesses in the body of the pregnant woman. Plass and Yoakam (37) conclude that the increased body activity as manifested by an Increased basal metabolic rate is due to the increased protoplastic mass alone and not to some inherent. 
mysterious body process of unknown nature. These workers prove their statement by subtracting the calculated heat production of the fetus from the total heat production of the prejnant woman, leaving the metabonic rate of the latter unaffected by gestation. Imnediately after deI1very the basal metabolic studies of the woman were found to be normal and the extra load as manifested by the basal metabolic studies before labor were found to correspond almost exactly with the messured netabolic rates of the newborn. However, Soule (41) concludes that the increased metabolism is not due to the fetus alone but to some change in the mother since, as was stated above, a higher conscentration of the thyroxin was demonstrated by him in the maternal blood than in the blood of the fetus. 


\section{Thyrotoxicosis During Pregnancy}

In a study of toxic thyrold during presnancy, one 1s Imnediately impressed by the scarcity of the condition. In the varlous clinics throughout this country and Europe the incldence is quite variable as one would expect with the existence of the so-called "golter belts". Another thing of interest is the dearth of material on the subject. The ilterature from 1921 to 1931 in the Index Medicus for the ten year period contains only sixteen articles in all languages dealing or bearing uoon the subject. Some of these were only case reports. Since then there has been some excellent records of observations in the larger clinics in the United States and Europe. The work of the Japanese should be brought aut on this subject but unfortunately none of them can be mentioned here because of unfamlliarity with the languase and the scarclty of abstracts in the English and German languages.

It hus been observed for many years that pregnancy has an effect on the activity of both the normal thyrold gland and the toxic gland. Observers have noticed that this effect may be an increased activity of the normal or pathological gland, that it may be a decrease, or that 
there may be no change at all. One thing is certain. With the activity of the thyroid increased, the activity of the ovary is reduced. This is especially brought out by Lahey (27), Gardiner-H111 (21), Davis (12), Clute and Daniels (8), Plass and Yoakam (37), and Beck (3). This explains the relative sterility which 1 s so often a part of the hyperthyroid state, as manifested by the low incldence which will be brought out below. Gardiner-Hill (2l) concludes from his studies that there is no evidence to show that pregnancy makes the case of hyperthyroldism worse. On the contrary, some of them are made distinctly better by pregnancy. Seltz (40) shows that pregnancy didnot affect the hyperthyroldism In $40 \%$ of his cases, but in $60 \%$ the toxic symptoms were made much worse. Mussey, Plummer and Boothby (36) did not find that pregnancy made the case of toxic thyrold any more difficult to handle or influenced it in any way. clute and Daniels (8) state that they have seen nothing occur in any woman with hyperthyroidism and pregnancy which didnot occur in the non pregnant thyrold cases of that tyoe. They state that multiple stage thyroldectomy has been fust as necessary in pregnant as in non pregnant women but no more so. However, these authorities belleve 
that pregnancy during hyperthyroidism is an added load for the patient to endure whether it does or doesnot affect the degree of toxicity which is present. Pregnancy increases the patients muscular work and adds to the metabolic requirements. These men state that it is their daily experience to note that thyrotoxic patients cannot tolerate the added loads and they feel certain from this standpoint, pregnancy is a serious burden in all severe thyrold intoxications, Beck (3) states that patients with Graves disease whose thyrolds have already been functioning excessivly before conception occured, improve subjectively during pregnancy.- This he attributes to the absence of the menstrual cycle which, in the non pregnant state, 1 s one of the main causes of increased body metabolism.

Wallace (44) studied 11,571 cases of pregnancy from the thyroid angle and concluded that there was no evidence to show that pregnancy was in any way responsible for exciting a thyrotoxicosis that made operation necessary later and in those where pregnancy occured following thyroldectomy, no recurrence of symptoms was caused by 1t. In his studies, Davis (11) (12) found that $41 \%$ of 520 pregnant women had thyrold hypertrophy. The condition 
was usually transient but elght of this group returned with toxic symptoms after dellvery. rlass and Yoakam (37) conclude through extensive basal metabolic studies that there is an increase in the thyrold activity in nearly all pregnant women. They show a gradual increase to about an average of $15 \%$ at term with a raold fall to normal in the first few days post partum. A greater rise and a slower fall to normal is indicative of pathological change Incldent to pregn:ancy.

Hinton (23) (24) states that $40 \%$ to $90 \%$ of all women have hypertrophy in pregnancy, and Frazler and Ulr1ch (20) show a conslstant 1ncrease of $15 \%$ in the basal metabolic rate in all women.

From what has gone before, we see that the course of a mildiy toxic case may be quite varlable. She may be distinctly better, she may be worse, or she may show no change. Shis is true of the more toxic cases and we see that this is distinctly not in accord with the ideas of Gellhorn (22), who states that an exophthalmic golter, though only moderately toxic, should not marry, if she marries she should not become pregnant, if she becomes pregnant she should be aborted.

As to the incldence of true toxic golter during preg- 
nancy, the figures of the larger clinics may be mentioned. Lahey (27) in Boston, in 3,678 patients he operated for toxic golter, found that 15 were pregnant, or an incldence of 0.41\%. Mussey and Plummer (35) at the Mayo clinic, found 42 cases in 7,228 pregnancles, or an incidence of $0.6 \%$. Yoakam (48) in Detro1t, (in a go1ter belt) found that 3.7\% of pregnant women had coexistant thyro1d disturbance. Markoe (33) in New York, found elght cases in 100,000 pregnancles in the New York Lying In. Wallace (44) In Brooklyn, found In ten years from 1921 to 1931, nine cases out of 11,571 pregnancies. The above cases as recorded by these men are toxic cases and there was no doubt as to whether the thyro1d was toxic or whether it was a "normal hypertrophy of presnancy" that was mentioned. Seltz (40) in Germeny records 112 toxic cases. Of these, $15 \%$ progressed to an alarming degree. In this group there were seven deaths, five therapeutic abortions, premature labor in eleven, thyroldectomy was performed in seven, and three had premature births. H1s results donot compare with those in the United States as far as incidence is concerned. Frazler and Jlrtch (20) give an incldence of $3.2 \%$ of women in whom thyroldectomy had been done, later developed thyrotoxicosis during pregnancy. 
- In drawing a conclusion from what has gone before, one is immediately at a loss to say anything specific. Two facts are prominent. First, the incidence of thyrotoxicosis during pregnancy varies in direct proportion to the incidence of uncomplicated goiter in that area. Second, the effect of pregnancy on an already toxic gland is variable and can be accurately determined only as pregnancy advances. This second statement shows just how difficult it is to follow the advice of Mussey (36) who says that the case in question must be studied very carefully and an attempt made to forsee what is going to happen and direct treatment along those ilnes. 
Elinical Considerations of Thyrold Toxemia In Pregnancy

Following are two case histories representing thyrold toxemia durling pregnancy. The first case represents the more common type seen almost daily. The second case is one of the more acute and serlous type which requires expert care in 1ts management. The similarity of these two cases is striking and seems to be only a matter of degree of toxic1ty.

\section{Case I}

Mrs H.S., married houseq1fe, age 20, primipara, had her last normal menstrual period on Apr1l 19, 1934. She had been perfectly well exceot for some nervousness, occasional loss of temper over trivial matters, and slight fullness in the neck since puberty. Her speech had always been rapid and thick with distinct lack of enunclation when she became the least bit excited. This condition had been present since puberty also.

She had had the usual childhood diseases and for the past year had been receiving injections of an autogenous vaccine for a mild form of pyodermia which had been quite persistant during this time. Other than this her past history was negative.

During the months of April, May and June, 1934 her condition was not much changed except for the normal changes which occur during the first trimester of pregnancy. About the fourth month she noticed the development of furuncles about the forearms and arms which vent on to supouration and were adequately drained. At this time she became more 
nervous, had a slight tremor, trachecardia and her hands were damp and warm. Her face was moderately flushed and her appetite was excesulve. The thyroid 8 land increased in size to the point where the boarders of the sternoclidomastold muscles no longer could be seen. This was diffuse hyoerplasia and the gland was soft. She had never been troubled with nausea or vomiting and her blood pressure was consistantly below 130 systollc and 90 diostolic. Her urine was negative for albumin and her blood picture was essentially normal.

The course on through pregnancy was uneventful. During the last trimester her condition remained as outlined above. She had a second attack of the skin infection at the seventh month which cleared up and gave her no further trouble.

She went into labor about 10 A.M. on February loth, 1935 and delivered a normal female child welohing elght pounds and thirteen ounces at $8: 30$ P.M. A second degree laceration was repalred and she returned home on the fourteenth day in fair physical condition.

At the time of this writing no deffinate statement can be made as to this oirls present condition. She is at the present time not much better than she was before delivery. She is still rather nervous and Irritable but the condition has been accentuated by some family troubles which have caused her no. little amount of concern and worry. She has however, a mild degree of subinvolution as a residual with a persistant vaginal discharge which has required rather vigorous treatment.

This type of case is seen most frequently by the obstetrician. It represents a type stressed by Daly and strouse (9) in thelr paper. These men stress the Importance of the symptoms of 1rritability, nervousness, 
and emotionallsm seen very frequently during pregnancy and place them clearly upon a thyrold basis. It seems to Indicate that pregnancy makes an already mildly toxic thyro1d gland worse and is distinctly not in accord with the 1deas of clute and Daniels (8) who consider any increase in toxicity of the thyrold gland as due to an Increase in the protoplastic mass alone. There seems to be an added factor here, possibly infection, but of course no conclusion can be drawn from the facts presented in a single case. Bothe (5) also brings out the importance of this type of case in his discussion. He points out the difficulty sometimes encountered in making the diagnosis of hyperthyroldism during pregnancy. Robinson (39) observed subinvolution very frequently In these cases and along with the symptom of tendency to bleed noted by Luker (29) In thyro1d cases constitute two symptoms not mentioned by the majority of writers.

Case II

Mrs A.J., 32 years of age, entered the Un1versity Hospital obstetrical service on January 9 , 1934, complaining of:

1. Tumor in the abdomen of four months duration.

2. Tremor, tachecardia, nervousness, tumor in the neck and loss of welght of elght years duration. 
She had always been. perfectly well unt1l elght years ago when she developed an enlargement in the neck which was diagnosed as golter. With the onset of her pregnancy one year later, she became very 1rritable, restless, and easily fat1gued. She was disturbed greatly with palpitation, sensitiveness to heat, and became quite dyspnoelc with slight exertion. Her apoetite became excessive. All the symotoms progressed and at the termination of the pregnancy s1x years ago she was operated upon. Two months later the patient returned to her surgeon complaining of persistance of the above symptoms. Reoperation was advised but refused and in compromise, the neck was 1rradiated with radium. There was marked recession of symptoms and much improvement in her general condition.

Since the onset of her present pregnancy seven months ago there has been a gradual but deffinate increase in the toxicity of her goiter. During the past four months her ankles have become progresalvely more edematous and one month before admission her physiclan observed a blood pressure of $180 \mathrm{~mm}$ of mercury, and that the urine contained albumin. A week later the syotolio pressure had gone to 210 .

The past history was essent1ally negative.

Physical examination upon admission showed the patient to be very nervous and restless with a damp warm skin. there was moderate exophthalmos with associated eje signs and a fixed anxious stare. Her face was markedly flushed. whe nose and throat examinations were negative, her teeth were in good repair. At the base of the neck there was a narrow scar of the previous operation and the skin of the area showed evidences of atrophic chages from excessive radiation. un each side of the trachea there was a mass about the size of a lemon of unusual consistancy, both were hard but elastic, slightly nodular and flxed to the surrouding tissue. No 1 sthmus was palpated. 
The lungs were clear throughout. The heart was moderately enlarged and the sounds were loud and snappy with an accentuation of the pulmonic second sound. There was a loud systolic murmur throughout the precordium. The blood pressure was 200 systollc and 100 diostolic.

The abdomen was negative except for a seven months pregnancy. Whe fetal position was left occlput anterior and the fetal heart sounds were heard in the lower left quadrant and recorded as 142 beats per minute. Vaginal examination revealed only the signa of pregnancy.

There was moderate pitting edema of both ankles, a marked fine ripld tremor of the fingers and hyperact 1 ve reflexes.

The laboratory revealed a three plus albumin in the urine, an erythrocyte count of $4,320,000$ with $80 \%$ haemoslobin, a white count of 9,100 and a normal differential. count. sxtensive blood chemistry was essentially negative, and the quanitative albumin measured 3 grams in 24 hours. The basal metabolic rate was plus 78. Roentgenographic studies of the chest showed moderate cardiac enlarsement, some passive congestion of both lung flelds, no prolongation of a substernal thyroid, and no evidence of an enlarged thymus gland. The electrocardiogram presented evidence of trachecardla and left axis deviation.

From the data above, the diagnosis was made of : 1. Persistant hyperthyroldism.

2. Pregnancy of seven months duration.

3. Nephrosis and possible ore-eclamptic toxemia.

She was treated conservatively with absolute bed rest, sedation, a low proteln diet which was salt free, small doses of calclum lactate and potassium citrate, several purges with magnesium sulphate, and repeated short courses of digatalis and Lugolis solution. The above trestment fave no noticable change in her condition. 
On February 12, 1934, a little over a month after her admission, the patient became alarmingly sick with evidences of thyroid crisis. Her temperature rose to 103 degrees, her pulse to 160 and her blood pressure to 220 systollc and 120 diastolic. Her urine was loaded with albumin and showed numerous granular casts. Her condition became progressively more critical until the pregnancy terminated spontaneously on the following day. Immediately she began to improve and within 48 hours the temperature had returned to normal, her pulse rate to 120 per minute and her blood pressure to 160 systolic and 100 diastolic. One week after delivery the basal metabolic rate was plus 47 and mounted again in one week to plus 66.

Continued bed rest and Lugol's solution was then carried out until on March 16, 1934 with a basal metabolic rate of plus 33 , and a oulse rate between 88 and 115 , partial thyroldectomy was performed, the right lobe of the thyrold being removed. The patient made an uneventful recovery and was discharged 10 days later with a basal rute of plus 42 and with orders to return after one month of rest.

She returned in one month and her basal metabollc rate was plus 60 . She was operated on April 27,1934 and the left Lobe was removed with a small remnant of the isthmus. The convalescence was uneventful and at the time of dischar e ten days later the basal metabolic rate was plus 14. A month later the patient reported that she felt perfectly well and for the first time in eight years she felt calm and had no palpitation.

This case 1llustrates the more severe form of thyrold intoxication which requires expert treatment. The added factor of thyrold toxemia superimposed upon a preeclamptic toxemia makes the case just that more difficult. 
For purposes of this discussion the factor of pregnancy toxemia will be omitted. Had the case beeniearlier in the course of pregnancy the treatment would no doubt have been different. To begin with the thyrold toxicity was severe enough without the added load of pregnancy to warrant operation with no appurent relief. Second, the progress of such a severe syndrome would lesd to a disasterous result if the average case had been handled as outilned above. Had this patient gone into a thyroid crisis the outcome would have been different. Third, surgical treatment was made very difflcult since there had been previous radiation therapy which, according to Flelsher (18) is distinctly not indicated and since Lugol's solution had been administered with no regard to the immediate or remote effect. A toxicity of 8 years duration will certainly have some residual effect upon this woman. She has evidences now of a thyrotoxic heart. In such a case where the intoxication 1 s so marked, thyroidectomy as her local surgeon advised 6 years ago, would have been the therapy of cholce. Since this was refused the surgery should have been done soon after pregnancy was discovered in order that any added strain might have been prevented. However, to follow the advice of Mussey, Plummer and 
Boothby (36) is very difficult since it cannot be determined just what effect pregnancy will have upon a toxic goiter. 
- Treatment of Hyperthyroidism During Pregnancy

of all the phases of thyrold disease in pregnancy, the two which have recelved the most consideration are the Incidence and the treatment. Also, there are as many different 1deas in regard to treatment as there are differences in the incldence throughout the world. A fact of interest is the evolution through which the ldeas of treatment of this condition has passed. It was long ago observed that the ingestion of sea-weed in people with enlargements of the neck caused that enlarsement to decrease in size. Out of this observation has come the use of lodine and later Lugol's solution as a method by which the size of the gland could be reduced but more Important, a method by which the toxicity of the gland could be reduced even though it is only temorary. Davidson (10) stresses the importance of orevent1tive treatment before a woman reuches the child bearing perlod of 11fe. It is well known what infection will do to a toxic goiter. Foci of Infection should be removed and if necessary, radical treatment may be necessury. This is especially true in areas of endemic oolter. The Ideas of Gellhorn (22) have been mentioned above. 
of course his 1deas are extremely radical and it is now known that the thyrold patient, though her chances for becoming pregnant have been reduced, has almost as good a chance for an entirely normal prejnancy and a normal baby as the woman without goiter. Th1s has been brought about by an increase in the fundamental understanding of the pathalogical changes responsible for the condition and more thorough understanding of the treatment both surgicyl and medical. Also, the physlcian knows what he may expect in regard to the response the woman makes when she places an added load on an already toxic thyroid. In reviewing the literature of the last few years, one $1 \mathrm{~s}$ Imoressed Immediatediy by the extreme differences which exist between the surgeon and internist as regards treatment. The argument seems to be as to whether a patient can be safely carried through pregnancy on medical management w1th or without Lugol's solution; whether it is fair to the patient to use Lugol's solution other than for the sole purpose of preparing her for thyroldectomy which may or may not be necessary later; and whether the use of Lugol's solution is contraindicated in the toxic adenoma. As will be pointed out later, the extremes may be quoted by authorities on these three questions. 
- There seems to be little difference in the general therapeutic measures employed elther in a case of hyperthyroidism in pregnancy or in pregnancy incident to hyperthyroidism. Al so the following general therapeutic measures are advocated by obstetriclan, surgeon and internist.

To begin with the patient should be placed at complete bed rest if she is at all toxic. Her general condition should be watched with great care in order that all secondany infections might be prevented. If such infection should oecur, strenuous treatment is required because the toxicity of the thyrold oland is more or less increased just as the diabetic responds to any infection. Her diet should be of an easily digestable type of high caloric value because the metabolic activities within the womans body have been whipped up and nore food is necessary since it is belng used up more ranidly. The diet should be of low protein content, since protein has the highest specific dynamlc action. Her fluid intake should be rather high since she persolres easily and has quite an excessive water loss in this manner. Another thing of importance is to divorce her frem the strain of emotion if possible. These people have a distinct tendency toward emotional instability and anythins which will pre- 
clpitate any emotional attack should be avolded. Hospitalization in such cases is ideal. The patient's bowels must be kept in good condition but strenvous drugs should be avoided, substituting the gastrointestinal lubricants and low enemita.

An important part of the treatment consists of sedation. These women are extremely irritable and usually sleep poorly and should be helped along these 11nes. This 18 especialiy brought out by Flelscher (18) and Day (13) who advocate a warm glass of milk and a mild sedative such as bromide or phenobarbital at bedtime. This sedation should be continued durinit the day also so that the patients irritable nervous system $1 \mathrm{~s}$ jut more or less at rest.

Another general measure of importance which should be brought out is the fact that the second stage of labor should be reduced to the minimum with the use of forceps, and that abortion except in the judgment of Hinton (24) should never be done for two reasons. First it is not Indicated with the newer methods of treatment, and second, it is dangerous in that thyroid crisis may be precipitated, as was pointed out by Lahey (27) in his , 
discussion on factors of mortality in thyrold disease which will be l1sted below. Xray and raditum are not effective and should be arolded because 1t makes the operative procedure more difflcult should it become necessary later. Th1s is brought out by Lahey (27) and Davidson (10).

Should Lugol's solution be used? Bothe (5) of Chicago states that small doses of Lugol's solution are indicated if the patient is moderately toxic in order that this type of patient may be carrled on through pregnancy. If this treatment is not effective plus the General medical management outlined above, the patient is placed into his surgical class and operated. His results have been excellent with the above routine. In the mild boarder line cases with very early symptoms, Bothe (5) feels should be operated early preceeded by lodine therapy to the point where the chances of a good result are maximum and thyrold crisis at a minimum. This he points out to be especially true in the toxic adenoma. Mussey, Plummer and Boothby (36) point out in this connection the danger of giving lodine in aporeciable amounts to patlents who have adenomatous goiters of the 
'non toxic type or to patients more than 25 years of age who have diffuse colloid goiters because of the danger of infliating hyperthyroldism. It is quite probable that collold golters, at least the larger percent of them, contain non palpable adenomas. This advice is also Given by Hinton (23) (24), Davis (11), (12) and Wallace (44) who add that lodine therapy used in adenama for anythin other than preparation for sur ical treatment is wrong, since the toxicity of that adenoma may be made distinctly worse.

Yoakam (48) points out the importance of the use of lodine as a prenatal measure in regions of endemic golter. He has made very scientific studies and shows the importance of monthly check uos on the thyrold gland wich should be carried on throush the post partum puriod. His studies included careful measurements of the isthmus of the thyrold glands of 937 patients but he concluded after this series that this method was not practical in followIng the progress of the patient and had no direct relationship to the toxicity of the gland in question. Another conclusion drawn from this work is the fact that lodine therapy did no good if given only in the last trimester of pregnincy. 
The work of Plass and Yoakam (37) tends to show that the use of lodine given prophylactically during oregnancy is unable unfformly to prevent gestational hypertrophy of the normal thyrold gland but seems to be quite effective In preventing such a change in glands which are pathologlcally altered when pregnancy begins and may actually lead to a reduction in the size of certain of the collold goiters.

Lahey (27) thinks that adenoma and exophthalmic goiter are a part of the same öeneral pathologic process and this observation in borne out by Davis (12) who advises the use of lodine in toxic adenomatous goiter as well as the exophthalmic type and has seen no bad results in this connection. I'his observation is also made by Falls (17). All the writers (5), (8), (35), (12), (37), bring out the Importance of the use of lodine in the tre tment of hyperemesis gravidarum whioh may be in resilty a manifestation of an early thyrold crisis. Bothe (5) treats all of his cases of persistant morning nausea and vomiting first by the use of Lugol's solution or thyrold extract. rhe use of thyroid extract in these cases seems to have originated In England and Germany and is not used so widely in the Unlted states. 
When should thyroldectomy be performed? This is probably one of the most difficult questions there is for the obstetrician to solve. His patient is at first placed In the hands of the internist who has a conservative regeme in mind. The patient is put on a strict type of management with bed rest, sedation and Lugol's solution. If this type of therapy fells and the patient continues toward a more acute toxemia the surgeon is called in. whe effects of Lugol's solution have been only slight and the surgeon is expected to operate and bring about a good result or else cure. These Bacts are brought out by wahey (27) who lists seven factors in mortality in thyrold surgery. They are: (1) walting, (2) age, (3) weloht loss and lowered resistance, (4) infection with jump in toxic symptoms, (5) toxicity and not basal metabolic readings, 16) operative procedures other than thyroldectomy, (7) pregnancy when allowed to advance without operation, otherwise it is not factor.

The above statements seem to indicate that radical treatment is the best. This conclusion is certainly not In accord with the observations of many observers on this question. Flelscher (18) conslders thyroldectomy as indieated only if symptoms advance to and alarming degree. 
He was compelied to do thyroldectomy only five times in 260 cases of Graves disease during pregnancy. In no case was he forced to interruot pregnancy. This seems to be the general concensus of oolnion as stated by Mussey and Plummer (35) who add that it is sufer to remove a toxic adenoma rather than try to carry them through on lodine therapy and also that it is safer to do thyroidectomy before any symptoms referable to the heart have developed thus preventing any permanent dammage to that organ. This conclusion $1 \mathrm{~s}$ drawn by Day (13) and Wallace (44) who point out that the danger lies in the lons continued thyrotoxicosis with a weakened heart. Wallace (44) c1tes the occasional case with onset during pregnancy which are rapid and fulminating in type and which require early operation. Day (13) stresses the importance of frequent post partum studies and the frequency of thyroid surgery necessary after delivery.

Gardiner-H1ll (2l) reports fatal termination in Graves disease during pregnancy as 50 percent and amelioration of symptoms which malntained after operation in 50 percent. This is certainly not in accord with the work of Mussey, Plummer and Boothby (36), Lahey (27), 
- Bothe (5) and Palls (17). Falls (17) has let some 80 with basal metabolic rates as high as plus 110 on medical management with good results. ne points out that the surgeon is more or less in a bad position if the case should come to surgery later because of the inability of that patient to successfully respond to lodine therapy a second time. He also points out that there is a possIbility even though it is remote, of producing hypothyroldism after operation before delivery when the extra load of pregnancy has been unloaded.

Fahrni (16) concludes that subtotal thyroldectomy should be performed if the patient is toxic and less than five months pregnant. After this time the patient should be carried through on medical management with the second stage of labor shortened and the thyrold surgery postponed t1ll later. He advises against pregnancy for two years but does no abortions if pregnancy does occur. Ihis is also the advice of W1lliamson (47). Hinton (23) (24) advises therapeutic abortion in cases of hyperthyroldism with myocardial involvement due to thyroid toxemia and In the fulminating type of thyrold dangerous to $11 \mathrm{fe}$. Frazier and Ulrich (20) and Polowe (38) point out the Imoortance of removal of the adenomas because of pressure 
on the recurrent laryngeal nerve and the trachea. They also advise the use of Lugol's solution after operation In an attempt to prevent return.

Much more has been written in the past three or four Jears concerning the etiology and prevention of thyroid disorders in the newborn than was written before this time. Not only should the woman involved be considered very carefully, but also her offsoring. Davis (12) shows that lodine is present only in traces in infants thyroids unless the mother has been given lodine when it is enormously Increased. He polnts out the lmportance of lodine therapy in preventing congenital goiter and cites a case In which the woman gave bitth to a child with a congenital golter after a gestation in which lodine was not a part of the prenatal care. The subsequent pregnancy with lodine as a prophylactic meisure resulted in a normal baby. Yoakam (48) shows that 60 percent of infints born of mothers who had no lodine had enlarsed thyroids and that there was no deviation from normal in the remaining 40 percent. After lodine therapy the incidence was reduced to 20 percent. After the introduction of lodized salt, the incidence in Detroit fell to 4 percent accordIng to Yoakam (48). Clute and Daniels (8) report no 
congenital golters in infants born of thyrotoxic mothers. Plass and Yoakam (37) stress the 1mportance of starting lodine therapy early in an attempt to prevent congenital golter since no result can be obtalned if the therapy is resorted to in the last trimester only. Hinton (23) (24) advises the use of lodine in collold golter in an effort to prevent fetal adenomata.

The subfect matter in this disucssion has been most 1nteresting. One $1 \mathrm{~s}$ 1mpressed by the wide differences of oplation which exist in the fleld and by the differences wh1ch one sees between forelgn and Americ n observers. Probably there is only one other complication of pregnancy about which there is more difference of oninion and that is the toxemlas of pregnancy. When one observes the miserable state these people are $1 n$, a stimulation of the Interest is immediate. Al so the change one observes after radical treatment is startling, and even though these differences of opinion exist, the treatment is comoletely sat1 sactory. 


\section{Conclusions}

1. Thyrold hypertrophy during pregnancy is common.

2. Hyperthyroldism during pregnancy is rare because increased thyrold secretion causes a decreased activity of the ovary.

3. Pregnancy may improve an already toxic thyroid giand, there may be no change, or the thyrotoxicosis may be made distinctis worse.

4. Exophthalmi goiter occurs more frequently than toxic adenoma during pregnancy only because adenoma ogcurs at a later time in life when the child bearing period is, to a large extent, over.

5. The complications of thyrold toxemia require very careful consideration and vigorous treatment.

6. Colloid golter presents no problem in treatment other than the administration of lodine or thyroid substance in order to prevent congenital golter in the newborn.

7. In mild cases no treatment is required. 
8, The dangers in adenoma seem to be not so much of those due to the toxemia itself, but more from the strain that pregnancy, labor, and delivery 1mpose upon organs already damaged by a long continued toxemia.

9. In dealing with both toxic and non toxic adenoma during pregnancy, lodine or thyroid extract should never be used at any time or in any dose except as a preparation preoperative measure because of the danger of increasing a thyrotoxicosis already present or creating one in a dormant gland.

10. There 1s a distinct difference of opinion as to the best therapy in toxic cases between surgeon and internist.

11. The presence of pregnancy in thyrotoxicosis doesnot Increase the operative risk of thyroldectomy.

12. Thyro1dectomy in the first five months of pregnancy seems the treatment of cholce. After this time, the patient should be carried through on medical management unless the toxicity of the gland should suddenly be increased when radical treatment should be instituted.

13. Hyperemesis gravidarum may be a manifestation of thyroid crisis and this type responds well to Lugol's 
solution.

14. Abortion is practically never indicated as far as the thyrotoxic condition is concerned. acute cardiac decompensation as a result of prolonged thyrold toxemia is certainly an indication.

15. The second stage of labor should be terminated as quickly as passible by the use of low forceps. 16. The best therapy is to forsee what is going to happen In a given case and direct treatment along those lines. If thyroldectomy seems inevitable, it should be done early. 


\section{BIBLIOGRAPHY}

1. Ansilmino, K.J.; Hoffman, F. \& Über den Milchsäuremsatz in der Schwangerchaft und selne Bezlehungen zum Kohlehydrat stoffwechsel zur Leber-und Sch1lddrüsenfuktion und zum Krelslauf, Arch. f. Gynak. 142:289-309,1930, Quoted by Bothe, F.A.: Hyperthyroldism Assoclated with Pregnancy, Amer. Jour. Obst. and Gynec., 25: 628-632 (May) 1933.

2. Ansilmino, K.J.; Hoffmen, F.: -.....- Arch. $f$. Gynak., 145:95-103,1931. Quoted by Bothe, F.A.: Hyperthyroldism Assoclated with Pregnancy, Amer. Jour. Obst. and Gynec,, 25:628-632 (May) 1933.

3. Beck, B.V.: städt1 schen Krankenhause zu Karlsruhe, Beltrage zur Klineschen Ch1rurg1e, 80:73-82,1921. Quoted by Flelscher, A.J.: Thyrotoxicosis Complicated by Pregnancy, Amer. Jour. Obst. and Gynec., 22: 273-276 (Aug) 1931.

4. Boothby, W.M.: Diagnosis and Treatment of Thyrold Disorders, Oxford Medicine, New York, oxford University Pross, 3:883-963,192?.

5. Bothe, P.A.: Hyperthyroidism Associated with Pregnancy, Amer. Jour. Obst. and Gynec., 25:628-632 (May) 1933.

6. Boyd, William: The Pathology of Internal Diseases, Lea and Febiger, Philadelphia, 1931, po 488-528.

7. Crott1, Andre: Thyro1d and Thymus, Lea and Pebiger, Philadelphia, 1922, pp 31-44.

8. Clute, H.M.; Daniels, D.H.: Hyperthyroldism and Pregnancy, Amer. Jour. of Med. Sclence, 179:477482 (Apri1) 1930.

9. Daly, P.A.; Strause, S.: The Thyrold During Pregnancy, Jour. Amer. Med. Assoc. 84-2:1798-1800 (June 13) 1925.

ló. Davidson, T.E.: Pregnancy Complicating Hyperthyroldism 
with Report of a Case, Jour. Iowa Med. Soc., 19 : 64-66 (Feb) 1929.

11. Davis, C.H.: Thyrold Hypertrophy and Pregnancy, with Data on Basal Hetabolic Rates and Calclum Content of the Blood, Jour. Amer. Mex. Assoc., 87:1004-1009 (Sept) 1926 .

12. Davis, C.H.: Prophylactic Treatment of Dysfunction of the Thyroid During Pregnancy and the Importance of Basal Metabolic Rate Studies, Amer. Jour. of Obst. and Gynec., 24,607-611 (oct) 1932.

13. Day, L.E.: Golter in Pregnancy, Ill. Med. Jour., 62:173-175 (Aug) 1932.

14. DuBo1s, E.P.: -..-- Quoted by Crott1, Andre: Thyroid and Thymus, Lea and Febiger, Philadelphia, 1922, pp 31-44.

15. Emmert, Max: The Thyroid Gland, Nebr. St. Med. Jour. $19: 23-27$ (Jan) 1934 .

16. Fahrn1, G.S.: Pregnancy Complicating Hyperthyroidism and Following Thyroidectomy, Canad. Med. Assoc. Jour., 23:645-647 (Nov) 1930 .

17. Falls, F.H.: Hyperthyroldism Complicating̈ Pregnancy, Amer. Jour. Obst. and Gynec., 17:536-549 (Apri1) 1929.

18. Flelscher, A.J. . Thyrotoxicosis Complicated by Pregnancy, Amer. Jour. Obst. and Gynec., 22:273-276 (Aug) 1931.

19. Pruhinsholz, A.: Thyroparathyrold Insufficiency and Pregnancy, Abstr. Jour. Amer. Med. Assoc., $79: 1961$ (Dec 2) 1922.

20. Frazier, C.H.; Ulrich, H.F.: Pathology of Thyrold Di sorders During Pregnancy, Amer. Jour. Obst. and Gynec., 24:870-879 (Dec) 1932.

21. Gardiner-H1ll, H.: Pregnancy Complicating Simple Golter and Graves Disease, Lancet, 1:120-124 (Jan 19) 1929. 
22. Gellhorn, H.: Exophthalmic Goiter and Pregnancy, Amer. Jour. Obst. and Gynec., 68:1132-1139 (Dec) 1932.

23. Hinton, J.W.: Significance of Thyroid Enlargement During Pregnancy, Amer. Jour. Obst. and Gynec., 13: 204-209 ( $\mathrm{Feb}) 1929$.

24. Hinton, J.W.: Hyperthyroldism Associated with Pregnancy, Amer. Jour. of Obst. and Gynec., 20:183-193 (Aug) 1930.

25. Knaus, H.: Thyrold Function in Pregnancy, Abstr. Jour. Amer. Med. Assoc., 81:2155 (Dec) 1923.

26. Knaus, H.: Thyro1d Function Durlni Pregnancy, Abstr. Jour, Amer. Med. Assoc., 84:558,1926.

27. Lahey, F.H.: Mortality Factors in Thyro1d Disease, Proc. Internat. Assemb. Interstate Post Grad. Med. Assoc. North Amer., 6:343-345,1931.

28. Loeb, L.; Bassett, R.B.: The Effect of Hormones of the Anterior Pituitary Gland on the Thyroid Gland in the Guinea Pig, Proc. Soc. Exp. Blob. and Med., 26: 860-862,1929.

29. Luker, S.G.: Exophthalmic Golter in Pregnancy and Labor (case) Proc, Roy. Soc. Med., 26:96-98 (Dec)
1932.

30. Marine, D.: Iodine in the Treatment of Diseases of the Thyroid Gland, Medicine, 6:127-141,1927.

31. Marlne, D.; Cipra, A.; Hunt, L.: Influence of Thyrold Gland on Increased Heat Production occuring During Pregnancy and Lactation, Jour. Metab. Research, 5: 277-291 (Apr11-June) 1924.

32. Marine, D.; Cipra, A.; Hunt, L.: Thyrold in Relation to Obstetrics and Gynecology, Surg. Gynec. Obst., 25: 272-279 (sept) 1917 .

33. Markoe, E.: ------ Quoted by Wallace, J.T.: Thyrotoxicosis in its Relationship to Pregnancy, Amer. 
, Jour. Obst, and Gynec., $26: 77-83$ (July) 1933.

34. Mayo, C.H•; Plummer, H.W.: The Thyrold Gland, C.V. Mo sby Co., St. Louis, April,1926.

35. Mussey, R.D.; Plummer, W.A.: Treatment of Goiter Complicating Pregnancy, Abstr. Proc. Staff Meet. Mayo Clinic, 6:373-375 (June 24) 1931 .

36. Mussey, R.D.; Plummer, W.A.; Boothby, W.M.: Pregnancy vomplicating Exophthalmic Goiter, and Adenomatous Goiter with Hyperthyroidism, Jour. Amer. Med. As soc., $87: 1009-1012$ (Sept 25) 1926 .

37. Plass, E.D.; Yoakam, W.A.: Basal Metabolic Studies in Normal Pregnant Women with Normal and Pathologic Thyroid Glands, Amer. Jour. Obst. and Gynec., 18: $556-568$ (oct) 1929 .

38. Polowe, D.: Thyroldectomy Late in Pregnancy, Successful Case, Jour. Amer. Med. Assoc., 99:2180-2181 (Dec 24) 1932.

39. Robinson, A.L.: Hyperthyroldism and Pregnancy, Jour. Obst. and Gynec. Brit. Bmpire, 29:296-298,1922.

40. Seltz, L.: Die Storingen der Inneren Sekrition in 1thren Bezlehungen zu Schwangerschraft, Geburt und Wachenbett, Gesellsch. f. Gynak., 15:213-475,1913, Quoted by Gardiner-Hill, H.: Pregnancy Complicating Simple Golter and Graves Diseases, Lancet, 1:120124 (Jan 19) 1929.

41. Soule, S.D.: Activity of the Thyroid Gland in Normal Pregnancy, Amer. Jour. Obst. and Gynec., 23:155-171 (Feb) $193 \%$

42. Stewart, J.D.; Menne, F.R.: Relationship of Iodine to Basal Metabolic Rate and to Changes in the Thyroid Gland in Pregnant Rabbits, Experimental studies, Endocrinology, 17:93-102 (Jan-Feb) 1933.

43. Virchow, R.: :---.-- quoted by Boyd, W.: Pathology of Internal Diseases, Lea and Febiser, Philadelphia, 
1 1922, pp 488-528.

44. Wallace, J.I.: Thyrotoxicosis in 1ts Relationship to Pregnancy, Amer. Jour. Obst. and Gynec., 26:77-83 (July) 1933.

45. Mard, G.G.: The Relation of the Thyrold Gland and Thyroldism to the Toxemias of Pregnancy, Surg. Gynec. and Obst., 9:617-621,1909.

46. Ward, G.G.: The Relation of the Thyroid Gland and Thyroldism to the Toxemias of Prejnancy, Further Studies, Surg. Gynec. and Obst., 15:192-196,1912.

47. Williamson, A.C.: Pregnancy Following Thyroidectomy, Amer. Jour. Obst. and Gynec., 14:196-202,1927.

48. Yoakam, W.A.: The Thyroid Gland: A Clinical study In a Region of Endemic Golter, Amer. Jour. of obst. and Gynec., 15:617-626 (May) 1928. 